\title{
Bacterivorous Nematodes Correlate with Soil Fertility and Improved Crop Production in an Organic Minimum Tillage System
}

\author{
Jan H. Schmidt ${ }^{1, * \mathbb{C}}$, Johannes Hallmann ${ }^{2}{ }^{(\mathbb{D}}$ and Maria R. Finckh ${ }^{1}(\mathbb{D}$ \\ 1 Ecological Plant Protection Group, University of Kassel, Nordbahnhofstr. 1a, 37213 Witzenhausen, Germany; \\ mfinckh@uni-kassel.de \\ 2 Institute for Epidemiology and Pathogen Diagnostics, Julius Kühn-Institute, Federal Research Centre for \\ Cultivated Plants, Messeweg 11/12, 38104 Braunschweig, Germany; johannes.hallmann@julius-kuehn.de \\ * Correspondence: jschmidt@uni-kassel.de; Tel.: +49-5542-981705
}

Received: 27 July 2020; Accepted: 18 August 2020; Published: 19 August 2020

\begin{abstract}
Reduced nutrient mineralization rates under minimum tillage are usually compensated by mineral fertilizer application. These, however, cannot be applied in organic farming systems. We hypothesized that an organic minimum tillage system based on frequent cover cropping and application of dead mulch would improve soil fertility and compensate for the potential negative effects of minimum tillage. Two long-term field experiments were set up in 2010 and 2011 to compare plowing versus minimum tillage including the application of transferred mulch. A second factor, the application of compost versus mineral potassium and phosphorus, was also compared. In 2019, soils were analyzed for soil $\mathrm{pH}$, organic carbon, macro- and micronutrients, microbial biomass, microbial activity, and total nematode abundance. In addition, performance of pea in the same soils was determined under greenhouse conditions. Across both experiments, macronutrients $(+52 \%)$, micronutrients $(+11 \%)$, microbial biomass $(+51 \%)$, microbial activity $(+86 \%)$, and bacterivorous nematodes $(+112 \%)$ increased in minimum tillage compared to the plow-based system. In the greenhouse, pea biomass was $45 \%$ higher in the soil that had been subjected to minimum tillage compared to the plow. In conclusion, soil fertility can be improved in organic minimum tillage systems, which include intensive cover cropping and the application of dead mulch, over plow-based systems.
\end{abstract}

Keywords: conservation agriculture; compost; soil quality; bio-test; macro- and micronutrients; free-living nematodes; microbial respiration; microbial biomass

\section{Introduction}

Organic farming systems are generally based on intensive soil tillage for seed bed preparation and weed control, which, in the long run, often lead to reduced soil fertility [1]. Intensive soil tillage increases microbial turnover rates and, thus, the nutrient availability required for plant growth. However, long-term intensive soil tillage can cause depletion of the soil organic carbon content and thus reduces soil fertility [2]. For a long-term improvement of soil fertility and its sustainable maintenance, organic production systems need to reduce the frequency and intensity of soil tillage and increase the organic matter supply to the soil. The resulting accumulation of organic carbon will likely increase the microbial activity and thus result in accelerated nutrient cycles [3-5]. However, minimum tillage generally tends to delay soil warming in spring; therefore, $\mathrm{N}$ mineralization rates are often too low to meet crop demands, especially in temperate climates [6]. For this reason, the application of conservation agriculture methods-i.e., the simultaneous application of minimum tillage, crop rotations, and residue retention—to organic farming systems may not necessarily improve soil fertility, 
even after 10 years of adaptation to the system [7]. Krauss et al. [5] reported similar results for yields of winter wheat, silage maize, and spelt in an organic long-term experiment, which were still $10 \%$ lower even after 10 years of reduced tillage in comparison with standard moldboard plowing, even though manure compost and slurry had been frequently applied. Although nutrient levels and biological soil components were generally higher under reduced tillage compared to plow tillage in the top $10 \mathrm{~cm}$ of the soil, the massively enhanced weed competition under reduced tillage likely reduced crop yields. Thus, organic minimum tillage systems need to be modified in order to provide sufficient levels of nutrients and weed control at the same time [8].

This could be achieved by the use of legume and non-legume cover crops and mulches. Cover crops are known, among other things, to conserve the nutrients of the previous crop for the following crop, increase the organic matter content, stimulate microbial activity, and suppress weeds [1]. Leguminous cover crops and, particularly, cover crop mixtures of brassicas with legumes have shown positive effects on microbial biomass and activities, as well as specific enzyme activities independent of the climatic region and weather conditions [9]. Furthermore, the use of cover crops can reduce weed seed banks in minimum tillage systems similar to levels in plow systems [10]. Organic mulch applications, referred to here as the harvest of cover crops and their subsequent application to a specific crop or field, have been shown to contribute substantially to soil fertility in organic minimum tillage systems [6]. All these measures also protect the soil from a range of environmental impacts, such as drought, wind and water erosion, and even plant diseases [11].

In combination with a long-term organic fertilizer strategy, such cropping systems should result in more sustainable cropping systems in which nutrient cycles are almost closed. For example, application of high-quality and certified composts that are free of pathogens, weeds, and toxic compounds can contribute to better plant performance in minimum tillage systems. In addition to nutrients, composts introduce additional microorganisms to the systems that may contribute to the suppression of soil-borne diseases and should, therefore, enhance overall soil fertility [12]. However, the evidence of disease suppression and the resulting soil fertility improvement through the use of composts often failed under field conditions in temperate climates due to variable environmental conditions and inadequate application rates of composts $[13,14]$. Thus, long-term field trials are required for a deeper understanding of the importance of compost in disease suppression and soil fertility improvement [15].

Soil fertility, which, in this context, is synonymously used to include both soil quality and soil health, can be assessed through chemical and biological indicators, such as organic carbon, $\mathrm{pH}$, micro- and macronutrients, microbial biomass, or microbial respiration [16]. Furthermore, free-living nematodes are considered important indicators of soil quality [17-20]. Different feeding types of nematodes occupy different niches within the soil food web and, hence, their classification and enumeration can determine certain carbon pathways. In a recent review, Bünemann et al. [16] pointed out that biological indicators are rarely used to assess soil health and quality, and that most of the commonly used indicators are "black box" indicators, such as $\mathrm{C}_{\text {mic }}$ and microbial respiration. They further criticize that such assessments are rarely linked to specific ecosystem services, which impedes the evaluation of their suitability as soil quality and health indicators.

Here, we investigated two long-term experiments that were set up in adjacent fields in 2010 and 2011 to assess the effects of an organic minimum tillage system on chemical and biological soil properties over time. The study specifically addressed the question of whether a crop rotation that includes cover crops and mulch applications can maintain or even improve soil fertility, and if this can even be further improved by the regular application of compost. Furthermore, the study investigated which chemical and biological parameters were best linked with biomass production in a pea (Pisum sativum L.) bioassay and could, therefore, serve as an indicator for soil fertility. The study compared a typical plow-based system $(25 \mathrm{~cm})$ with a minimum tillage system (max. $15 \mathrm{~cm})$, where the minimum tillage system included application of transferred dead mulch to potatoes (experiment 1: 2014, 2018; experiment 2: 2015, 2019) (Figure 1). The second factor analyzed was the application of yard waste compost at a rate of $\sim 5 \mathrm{t}$ (ha a) ${ }^{-1}$ dry matter (DM) compared to equivalent amounts of mineral 
phosphorus (rock phosphate) and potassium $\left(\mathrm{K}_{2} \mathrm{SO}_{4}\right)$ fertilization. We hypothesized that (i) minimum tillage with mulch applied to potatoes increases soil fertility compared with a plow-based inversion tillage system without mulch, (ii) regular compost application improves chemical and biological soil parameters compared to mineral fertilization, and (iii) soil fertility indicators, including bacterivorous nematodes, are positively correlated with pea biomass production and reduced root disease severity in the greenhouse bioassay.

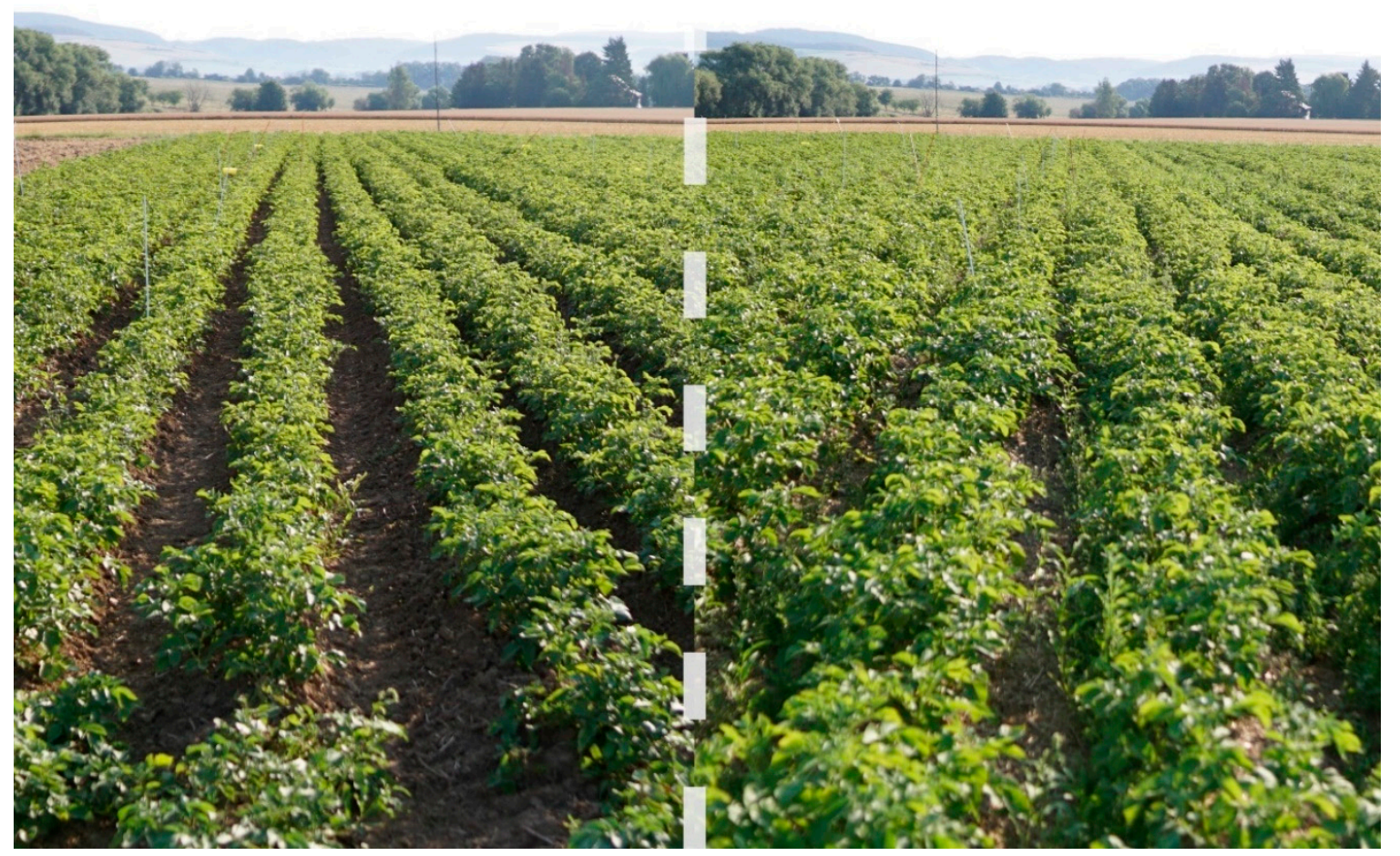

Figure 1. Differences in potato canopy closure on 24 July 2019 prior to flowering (BBCH 59) due to variation in soil fertility. Left: Plow tillage without mulch; right: Minimum tillage with mulch. Potatoes were planted at the end of May. Photo: S. Junge.

\section{Materials and Methods}

The two long-term experiments originally started in 2010 and 2011 in adjacent fields located on the organic experimental farm of the University of Kassel (Kassel, Germany) in Neu-Eichenberg $\left(51^{\circ} 22^{\prime} 51^{\prime \prime} \mathrm{N}, 9^{\circ} 54^{\prime} 44^{\prime \prime} \mathrm{E}, 231 \mathrm{~m}\right.$ above sea level with an eastern incline of $3 \%$ ). The soil type is a Haplic Luvisol with 3.3\% sand, 83.4\% silt, and 13.3\% clay (United States Department of Agriculture classification $\mathrm{Zc}$, Washington, DC, USA). Liming $\left(\mathrm{CaCO}_{3}\right)$ was applied to all treatments at $2 \mathrm{t} \mathrm{ha}^{-1}$ in August/September 2019.

The experiments have been described in detail in Schmidt et al. [21], and all crops grown since the start are shown in Table 1. In brief, both experiments consist of a split-plot design with four replicates and tillage as the main factor $\left(12 \times 60 \mathrm{~m}^{2}\right)$ : (1) Minimum tillage by chisel plowing or shallow rototilling $(5-15 \mathrm{~cm})$ including the application of dead mulch to potatoes under minimum tillage versus (2) conventional moldboard plow tillage $(20-25 \mathrm{~cm})$. The dead mulch applied to potatoes under minimum tillage was typically obtained from rye/pea or triticale/vetch cover crop mixtures that were chopped $(<10 \mathrm{~cm})$ and applied at $10-15 \mathrm{t} \mathrm{ha}^{-1}$ on average with an adapted manure spreader. The $\mathrm{C} / \mathrm{N}$ ratio of the mulch ranged between 20 and 25 . Each main tillage plot $\left(12 \times 60 \mathrm{~m}^{2}\right)$ was split into eight $6 \times 15 \mathrm{~m}^{2}$ subplots, of which four of the subplots received $\sim 5 \mathrm{t}$ dry matter (ha yr) ${ }^{-1}$ of a high-quality yard waste compost that was applied manually. The remaining four subplots received potassium 
$\left(\mathrm{K}_{2} \mathrm{SO}_{4}\right)$ and phosphorus (rock phosphate) fertilizer equivalent to their amounts in the respective composts. For details of the compost used between 2012 and 2015, see Schmidt et al. [21]. Composts used thereafter were of similar quality. In total, 32 plots were investigated ( 2 field experiments $\times 4$ replicates $\times 2$ tillage treatments $\times 2$ fertilizer treatments).

Table 1. Sequence of crop rotations for the two field experiments including cash and cover crops (in brackets) from 2010 until 2020.

\begin{tabular}{|c|c|c|c|}
\hline Year & Crop Type & Experiment 1 & Experiment 2 \\
\hline 2010-2011 & $\begin{array}{l}\text { main } \\
\text { cover crop }\end{array}$ & $\begin{array}{c}\text { grass-clover } \\
-\end{array}$ & \\
\hline 2011-2012 & $\begin{array}{l}\text { main } \\
\text { cover crop }\end{array}$ & grass-clover & $\begin{array}{c}\text { grass-clover } \\
-\end{array}$ \\
\hline 2012-2013 & $\begin{array}{l}\text { main } \\
\text { cover crop }\end{array}$ & winter wheat & $\begin{array}{c}\text { grass-clover } \\
-\end{array}$ \\
\hline $\begin{array}{l}2013-2014 \\
2014-2015\end{array}$ & $\begin{array}{l}\text { main } \\
\text { cover crop } \\
\text { main }\end{array}$ & $\begin{array}{c}\text { summer vetch/clover } \\
\text { potatoes }\end{array}$ & winter wheat \\
\hline $2015-2016$ & $\begin{array}{l}\text { cover crop } \\
\text { main } \\
\text { cover crop }\end{array}$ & $\begin{array}{c}\text { winter rye } \\
\text { winter triticale } \\
\text { berseem clover (summer) }\end{array}$ & $\begin{array}{l}\text { summer vetch/clover } \\
\text { potatoes } \\
\text { winter rye }\end{array}$ \\
\hline 2016-2017 & $\begin{array}{l}\text { main } \\
\text { cover crop }\end{array}$ & winter wheat & $\begin{array}{c}\text { winter triticale } \\
\text { berseem clover (summer) }\end{array}$ \\
\hline 2017-2018 & main & & winter wheat (terminated due to drought) \\
\hline 2018-2019 & $\begin{array}{l}\text { cover crop } \\
\text { main }\end{array}$ & $\begin{array}{l}\text { winter triticale/winter vetch } \\
\text { potatoes }\end{array}$ & berseem clover (summer) \\
\hline 2019-2020 & $\begin{array}{l}\text { cover crop } \\
\text { main } \\
\text { cover crop }\end{array}$ & $\begin{array}{l}\text { winter rye } \\
\text { grass-clover }\end{array}$ & $\begin{array}{c}\text { winter triticale/winter vetch } \\
\text { potatoes } \\
\text { winter rye }\end{array}$ \\
\hline
\end{tabular}

Soil samples were collected after the first differential tillage (Experiment 1: Winter 2012/2013, Experiment 2: Fall 2013), in September after the first potato crop (Experiment 1: 2014, Experiment 2: 2015), and in October 2019 (Experiment 1: During grass-clover crop, Experiment 2: After potatoes) (compare Table 1). Soil samples of the first two sampling dates of each experiment were taken from the top soil $(0-15 \mathrm{~cm})$ of each plot with a soil corer $(2.4 \mathrm{~cm}$ diameter). In 2019, about 110 soil cores were taken randomly from each plot center $(4.5 \times 10 \mathrm{~m})$ with an Edelmann corer $(8 \mathrm{~cm}$ diameter, $15 \mathrm{~cm}$ soil depth). Soils were subsequently sieved to $1 \mathrm{~cm}$ and stored in plastic bags at $4{ }^{\circ} \mathrm{C}$ until processing.

\subsection{Soil Nutrient Analyses}

Soil nutrients were analyzed by the Landesbetrieb Hessisches Landeslabor (LHL, http://www.lhl. hessen.de) two years after the experimental setup, i.e., 2012 in Experiment 1 and 2013 in Experiment 2, and for both experiments in 2019. The former analysis was performed on pooled samples of each experimental field, and $\mathrm{pH}$ and macronutrients were determined (Table 2). In 2019, aliquots of $500 \mathrm{~mL}$ soil of each plot were analyzed for macro- and micronutrients, soil organic carbon $\left(\mathrm{C}_{\mathrm{org}}\right)$, total soil nitrogen $\left(\mathrm{N}_{\text {total }}\right), \mathrm{pH}$, and salt $(\mathrm{KCl})$ according to the "Verband Deutscher Landwirtschaftlicher Untersuchungs- und Forschungsanstalten" (VDLUFA) standards [22].

Table 2. Soil macronutrient, $\mathrm{pH}$, and organic carbon concentrations in the fields used for Experiments 1 (2012) and 2 (2013) prior to the start of differential tillage and fertilizer applications.

\begin{tabular}{cccc}
\hline Soil Parameter & Unit & Experiment 1 & Experiment 2 \\
\hline $\mathrm{pH}$ & & 6.3 & 5.9 \\
$\mathrm{P}_{2} \mathrm{O}_{5}$ & $\mathrm{mg} \mathrm{kg} \mathrm{soil}^{-1}$ & 120 & 90 \\
$\mathrm{~K}_{2} \mathrm{O}$ & $\mathrm{mg} \mathrm{kg} \mathrm{soil}^{-1}$ & 180 & 100 \\
$\mathrm{MgO}$ & $\mathrm{mg} \mathrm{kg} \mathrm{soil}$ & 140 & 150 \\
$\mathrm{C}_{\text {org }}$ & $\%$ & 1.22 & 1.16 \\
\hline
\end{tabular}




\subsection{Biological Assessments}

Microbial biomass was determined two years after start of the experiments and directly after the first differential tillage (2012 and 2013), four years after start of the experiments (2014 and 2015), and 9 and 8 years after starts of Experiments 1 and 2 (2019), respectively. Soil samples were sieved to $2 \mathrm{~mm}$, and soil moisture was measured gravimetrically after drying at $105^{\circ} \mathrm{C}$. After removing plant roots, soil microbial biomass was calculated via chloroform fumigation extraction, following the instructions and equations of Vance et al. [23]. The resulting microbial biomass carbon $\left(\mathrm{C}_{\text {mic }}\right)$ and nitrogen $\left(\mathrm{N}_{\text {mic }}\right)$ values were divided by 0.45 and 0.54 , respectively, which are the correction factors of the extractable microbial biomass in soils [24,25]. Extracts were stored at $-15^{\circ} \mathrm{C}$ until organic $\mathrm{C}$ and total $\mathrm{N}$ in extracts were measured using an automatic $\mathrm{C}$ and $\mathrm{N}$ analyzer (Multi C/N, Fa Analytik Jena).

Microbial respiration, as an indicator for microbial activity, was determined from the sieved soils in 2019. Soils were moistened to $50 \%$ water-holding capacity for seven days prior to analysis. Two $70 \mathrm{~g}$ sub-samples of each soil were then filled into glass beakers placed in preserving jars that contained $20 \mathrm{~mL}$ water to prevent drying out of the soils. Glass beakers with $15 \mathrm{~mL}$ of $0.5 \mathrm{~mol} \mathrm{NaOH}$ were additionally placed in the jars. Six blinds without soil were used as controls. Jars were closed hermetically and incubated for seven days at $20^{\circ} \mathrm{C}$. After incubation, glass beakers with $\mathrm{NaOH}$ were stored in vacuum desiccators filled with soda-lime to avoid evaporation of the $\mathrm{CO}_{2}$. The total $\mathrm{CO}_{2}$ concentration in the $\mathrm{NaOH}$ was assessed via $\mathrm{HCl}$ titration. For this, a solution containing $3 \mathrm{~mL}$ of the $\mathrm{NaOH}, 30 \mathrm{~mL}$ water, $3 \mathrm{~mL} 0.5 \mathrm{~mol} \mathrm{BaCl}$, and two drops of phenolphthalein was stirred and titrated with $0.1 \mathrm{~mol} \mathrm{HCl}$ until the color changed to rose. This back-titration titrated the excessive $\mathrm{NaOH}$. The soil respiration was calculated according to the formula:

$$
\mathrm{mg} \mathrm{CO}(\mathrm{g} \mathrm{DMd})^{-1}=\frac{(\mathrm{VB}-\mathrm{VS}) \times \mathrm{F} \times 2.2 \times 100}{\mathrm{FM}(\mathrm{g}) \times \mathrm{DM}(\%) \times \mathrm{d}}
$$

$\mathrm{VB}$ and VS are the volumes of $\mathrm{HCl}$ titrated to the blinds and samples, respectively, $\mathrm{F}$ is the dilution factor ( $3 \mathrm{~mL}$ aliquot of the $15 \mathrm{~mL} \mathrm{NaOH}$ samples means $\mathrm{F}=5$ ), 2.2 corresponds to the amount of $\mathrm{CO}_{2}$ $(\mathrm{mg})$, which refers to $1 \mathrm{~mL}$ of the titrated $0.1 \mathrm{~mol} \mathrm{HCl}, \mathrm{FM}$ and $\mathrm{DM}$ are the fresh matter $(\mathrm{g})$ and dry matter (\%) of the soil samples, respectively, and $\mathrm{d}$ is the incubation time (days) of the samples at $20^{\circ} \mathrm{C}$.

For nematode analysis, $250 \mathrm{~mL}$ soil aliquots were processed with the Oostenbrink elutriator [26]. Nematodes were collected on three mounted $45 \mu \mathrm{m}$ sieves, were washed into a beaker, and were transferred onto an Oostenbrink dish to get a clean sample. After incubation at room temperature for $48 \mathrm{~h}$, the nematodes in the Oostenbrink dish were collected on a $20 \mu \mathrm{m}$ sieve and transferred to a plastic tube, which was then filled up to $30 \mathrm{~mL}$ with tap water. Nematode densities were counted from three times $1 \mathrm{~mL}$ aliquots at $40 \times$ magnification under a compound microscope. Final nematode densities were given as nematodes per $100 \mathrm{~mL}$ soil. Nematodes were classified to the family level by morphological identification of 100 individuals per sample using the key of Bongers [27]. Nematode families were summarized into bacterivorous, fungivorous, herbivorous, and omnivorous/predatory feeding types by using the nematode indicator joint analysis web tool [28].

\subsection{Greenhouse Study for Fertility Assessments}

The soil fertility of each of the 32 soil samples ( 2 experiments $\times 4$ replicates $\times 4$ soils) was examined in a pea bioassay under greenhouse conditions at $21^{\circ} \mathrm{C} / 18^{\circ} \mathrm{C}$ day/night temperatures. To check if the difference in soil fertility might be associated with better plant performance under nematode pressure, the soil was artificially inoculated with the root lesion nematode Pratylenchus penetrans. For this, five sub-samples with $700 \mathrm{~mL}$ soil each were filled in $11 \times 11 \times 12 \mathrm{~cm}$ pots, and the pots were organized as a randomized complete block ( 160 pots). Five surface-sterilized ( $70 \%$ ethanol for $5 \mathrm{~min}$ ) and pre-germinated ( 2 days) pea seeds were planted per pot, and reduced to three plants per pot after one week. On the day of plant thinning, mixed stages of P. penetrans (males, females, juveniles, and eggs) were inoculated in all soils at densities of 1000 nematodes and eggs per $100 \mathrm{~mL}$ soil. 
The inoculation density was based on repeated pre-experiments with inoculation densities of 0,500 , 1000, 2000, and 3000 nematodes per $100 \mathrm{~mL}$ soil of the Experiment 1 field. The pea biomass reduction was $11 \%$ and $12 \%$ in the pre-trials 1 and 2, respectively, after inoculation with 1000 P. penetrans per $100 \mathrm{~mL}$ soil.

Nematode inoculum was obtained from 8-12-week-old carrot disc cultures that were chopped, and the inoculum was extracted with Oostenbrink dishes [29]. The nematodes were stored at $7{ }^{\circ} \mathrm{C}$ until use in the experiment.

Pots were watered to approximately $50 \%$ water-holding capacity every two to three days. The four tables with the pots were re-randomized each week to compensate for differences in illumination from neighboring cabins. Plants were harvested at $\mathrm{BBCH} 71$ after a growth period of 80 days, and aboveground dry matter (DM) after drying at $105^{\circ} \mathrm{C}$ for $24 \mathrm{~h}$, the number of pods, and root fresh weight were determined. A root rot disease index (0-100) was calculated based on the assessment of external root lesions, and lesion lengths were measured according to Šišić et al. [30] and Pflughöft [31]. Pratylenchus penetrans was extracted from pea roots via mist chambers [26]. For this, roots were cut in $1 \mathrm{~cm}$ pieces and placed on sieves on glass Petri dishes. Roots were kept moist for four weeks by spraying with water for 30 s every $5 \mathrm{~min}$. Once a week, nematodes settled at the bottom of the Petri dish were transferred into PET bottles and stored at $4{ }^{\circ} \mathrm{C}$ until the end of the extraction procedure. The final suspension was adjusted to $50 \mathrm{~mL}$, and $3 \mathrm{~mL}$ aliquots were taken to count the number of P. penetrans.

\subsection{Data Processing and Statistical Analysis}

Statistical analyses were performed with R version 3.6.0 [32] using the packages "nlme" [33] for analyses via linear mixed models and "emmeans" [34] for multiple comparisons of treatments, back-transformed means, and standard errors. The "car" package [35] was used to test the applied models for their variance homogeneity via Levene tests. In case of violations of variance homogeneity, linear mixed-effects models (lme) were adjusted with the weighting function "varIdent" [36]. This function enables the model to use individual standard errors for each factor level (combination). If more than one factor showed inhomogeneous variances, the model with the lowest Akaike information criterion values was used based on log likelihood tests according to the description of Zuur et al. [36]. Fixed factors were tillage and fertilizer, whilst random factors were experiments, field replicates, and tillage, each nested in the preceding factor. Thus, the formula used in $\mathrm{R}$, including an example of a weighting function with two factors that showed inhomogeneous variances, was:

$$
\begin{gathered}
\text { lme }(y \sim \text { tillage } \times \text { fertilizer, random }=\sim 1 \text { |experiment/ replicate/ } \\
\text { tillage, weights }=\text { varIdent }(\text { form }=\sim 1 \mid \text { tillage } \times \text { fertilizer }), \text { data }=\text { data })
\end{gathered}
$$

For the data analysis of the greenhouse experiment, the random term was extended to "random = $\sim 1$ experiment/replicate/ (greenhouse replicate/ tillage)".

Spearman's $r_{s}$ rank correlations were used to study the relationship of chemical and biological indicators, as well as their correlation with pea biomass production, root disease severity, and the number of P. penetrans in roots, by using the "rcorr" function of the R-package "Hmisc" [37]. Results were visualized for each field experiment separately using the R function "corrplot" of the "Hmisc" package based on the $p<0.05$ significance level.

\section{Results}

Both field experiments were maintained according to the ceteris paribus principle. However, the severe drought in 2018 required some modifications in Experiment 2. Due to the drought and also high weed infestation, the winter wheat was terminated two months earlier than usual (Table 1). The following summer cover crop (berseem clover) did not germinate because of the drought and, 
therefore, a triticale/winter vetch cover crop was sown about two months after termination of the winter wheat.

Due to the time shift between the two field experiments (e.g., the last applications of dead mulch in Experiments 1 and 2 dated back 16 and four months, respectively), the experiment was initially included as a fixed factor in the linear model. Hence, interactions of the field experiment with tillage and fertilizer could be analyzed. In detail, experiments interacted with tillage regarding boron, $\mathrm{KCl}$, $\mathrm{C}_{\mathrm{mic}} / \mathrm{C}_{\text {org }}$, bacterivorous, and fungivorous nematodes $\left(\mathrm{F}_{1,6}>8.1, p<0.03\right.$, Table 3$)$, but not with compost for any of the determined soil parameters. The interactions were, with the exception of fungivorous nematodes, expressed by a lower differentiation of minimum tillage to plow tillage in Experiment 2 compared to Experiment 1 . As an example, boron concentrations were $51 \%$ and $14 \%$ higher under minimum tillage compared to plow tillage in Experiments 1 and 2, respectively. This justified the analysis of treatment effects across both field experiments using the experiment as a random factor (Table 3).

\subsection{Effects of Tillage System and Fertilizer Application on Chemical and Biological Soil Properties}

Minimum tillage and, in part, compost application increased the amounts of most macronutrients in the soil. Initial contents of $\mathrm{P}_{2} \mathrm{O}_{5}, \mathrm{~K}_{2} \mathrm{O}, \mathrm{MgO}$, and $\mathrm{C}_{\text {org }}$ in the top $25 \mathrm{~cm}$ soil two years after the start of the field experiments (2012/2013) were, on average, 105, 140, 145 (all in $\left.\mathrm{mg}(\mathrm{kg} \text { soil })^{-1}\right)$, and 1.2\%, respectively (Table 2). In 2019, these values were lower or similar under plow tillage with mineral fertilization (Table 3). In comparison, values were slightly higher under plow tillage with compost fertilization; in particular, $\mathrm{C}_{\text {org }}$ increased by $20 \%$ (Tables 2 and 3). In contrast, minimum tillage with compost or mineral fertilization increased $\mathrm{P}_{2} \mathrm{O}_{5}, \mathrm{~K}_{2} \mathrm{O}$, and $\mathrm{C}_{\text {org }}$ by $23 \%, 129 \%$, and $57 \%$ compared to the initial values, respectively. This translated to higher $\mathrm{P}_{2} \mathrm{O}_{5}, \mathrm{~K}_{2} \mathrm{O}$, and $\mathrm{C}_{\text {org }}$ values of $48 \%, 147 \%$, and $34 \%$, respectively, under minimum tillage compared to plow tillage in 2019, regardless of whether mineral or compost fertilization was applied (Table 3 ). Moreover, $\mathrm{N}_{\text {total }}$ was $25 \%$ higher under minimum tillage than plow tillage (Table 3).

In the present study, $\mathrm{pH}$ was considerably higher in all treatments in 2019 than when first measured in 2012 and 2013 (6.1, Table 2). Differences in pH between treatments were not observed.

The salt content varied between 486 (plow tillage without compost) and 762 (minimum tillage with compost) $\mathrm{mg} \mathrm{KCl} \mathrm{L}^{-1}$, which translates to electrical conductivities (EC) of 0.9 and $1.4 \mathrm{mS} \mathrm{cm}^{-1}$, respectively.

Soil micronutrients varied in a distinct pattern among treatments. While copper concentrations were highest under plow tillage with mineral fertilization, manganese and iron concentrations were similar across all treatments (Table 3). In contrast, zinc and boron concentrations were significantly higher under minimum than under plow tillage, irrespective of the fertilization strategy.

In general, soil biological properties were enhanced by minimum tillage compared to the plow tillage systems. For $\mathrm{C}_{\text {mic }}$, the differences between minimum and plow tillage, as well as, in part, between the compost and mineral fertilization, increased over time (Figure 2). This is reflected by significant interactions of sampling date (year) and tillage in both experiments $\left(\mathrm{F}_{2,30}>7.7, p \leq 0.002\right)$. The status quo analysis was taken after the first differential tillage and compost application (2012, 2013), two years after the start of the experiment. Initial $C_{\text {mic }}$ values in Experiments 1 and 2 were $60 \%$ and $27 \%$ higher under minimum tillage with mineral fertilizer than under plow tillage with mineral fertilizer. However, those differences were not statistically significant due to large standard errors (Figure 2). 
Table 3. Means ( \pm SE) of chemical and biological soil parameters in 2019, nine (Experiment 1) and eight (Experiment 2) years after the start of the field experiments. The factors studied were plow and minimum tillage combined with either compost fertilization $\left(<5 \mathrm{t}(\text { ha } \mathrm{a})^{-1}\right)$ or mineral potassium and phosphorous application equivalent to contents in the respective composts. The results are averaged across both independent field experiments, as only few interactions between experiment (Exp) and tillage (T) and no interactions between Exp and fertilizer (not shown) occurred.

\begin{tabular}{|c|c|c|c|c|c|c|c|c|c|c|}
\hline \multirow[b]{2}{*}{ Soil Parameter } & \multirow[b]{2}{*}{ Unit } & \multicolumn{4}{|c|}{ Plow Tillage } & \multicolumn{5}{|c|}{ Minimum Tillage } \\
\hline & & Mineral & & Compos & & Mineral & & Compost & & $\operatorname{Exp} \times T$ \\
\hline $\mathrm{pH}$ & & 6.56 & \pm 0.20 & 6.74 & \pm 0.20 & 6.70 & \pm 0.20 & 6.74 & \pm 0.19 & n.s. \\
\hline $\mathrm{P}_{2} \mathrm{O}_{5}$ & $\mathrm{mg} \mathrm{kg} \mathrm{soil}^{-1}$ & $71^{a, 3}$ & \pm 28 & $103^{a b}$ & \pm 29 & $125^{\mathrm{b}}$ & \pm 28 & $133^{\mathrm{b}}$ & \pm 29 & n.s. \\
\hline $\mathrm{K}_{2} \mathrm{O}$ & $\mathrm{mg} \mathrm{kg} \mathrm{soil}{ }^{-1}$ & $124^{\mathrm{a}}$ & \pm 9.4 & $136^{\mathrm{a}}$ & \pm 11.2 & $319^{b}$ & \pm 9.1 & $324^{\mathrm{b}}$ & \pm 23.5 & n.s. \\
\hline $\mathrm{MgO}$ & $\mathrm{mg} \mathrm{kg} \mathrm{soil}^{-1}$ & $166^{\mathrm{a}}$ & \pm 11.9 & $174^{a b}$ & \pm 12.1 & $172^{\mathrm{a}}$ & \pm 11.8 & $189^{\mathrm{b}}$ & \pm 12.4 & n.s. \\
\hline $\mathrm{Cu}$ & $\mathrm{mg} \mathrm{kg} \mathrm{soil}^{-1}$ & $3.29^{b}$ & \pm 0.22 & $2.99^{\mathrm{a}}$ & \pm 0.22 & $3.07 \mathrm{ab}$ & \pm 0.23 & $3.15^{a b}$ & \pm 0.26 & n.s. \\
\hline $\mathrm{Zn}$ & $\mathrm{mg} \mathrm{kg} \mathrm{soil}^{-1}$ & $5.35^{\mathrm{a}}$ & \pm 0.25 & $6.5^{b}$ & \pm 0.47 & $6.94^{b}$ & \pm 0.25 & $7.15^{a b}$ & \pm 0.66 & n.s. \\
\hline $\mathrm{Mn}$ & $\mathrm{mg} \mathrm{kg} \mathrm{soil}^{-1}$ & 374 & \pm 34 & 354 & \pm 34 & 394 & \pm 36 & 357 & \pm 34 & n.s. \\
\hline B & $\mathrm{mg} \mathrm{kg} \mathrm{soil}^{-1}$ & $0.65^{\mathrm{a}}$ & \pm 0.11 & $0.71^{\mathrm{a}}$ & \pm 0.11 & $0.89^{b}$ & \pm 0.11 & $0.91^{b}$ & \pm 0.11 & 0.001 \\
\hline $\mathrm{Fe}$ & $\mathrm{mg} \mathrm{kg} \mathrm{soil}^{-1}$ & 118 & \pm 13 & 117 & \pm 13 & 121 & \pm 13 & 120 & \pm 13 & n.s. \\
\hline Salt $(\mathrm{KCl})$ & $\mathrm{mg} \mathrm{l}^{-1}$ & $486^{\mathrm{a}}$ & \pm 49 & $582 \mathrm{abc}$ & \pm 67 & $700^{\mathrm{b}}$ & \pm 49 & $762^{c}$ & \pm 50 & 0.03 \\
\hline $\mathrm{C}_{\text {org }}$ & $\%$ & $1.27^{\mathrm{a}}$ & \pm 0.06 & $1.52^{\mathrm{b}}$ & \pm 0.07 & $1.79^{c}$ & \pm 0.06 & $1.95^{\mathrm{d}}$ & \pm 0.07 & n.s. \\
\hline $\mathrm{N}_{\text {total }}$ & $\%$ & $0.15^{\mathrm{a}}$ & \pm 0.007 & $0.18^{\mathrm{b}}$ & \pm 0.008 & $0.2^{c}$ & \pm 0.006 & $0.21^{\mathrm{c}}$ & \pm 0.008 & n.s. \\
\hline Microbial respiration & $\mu \mathrm{g} \mathrm{CO}_{2}(\mathrm{~g} \text { dry soil d })^{-1}$ & $33.9^{\mathrm{a}}$ & \pm 1.3 & $41.6^{\mathrm{b}}$ & \pm 1.2 & $66.7^{c}$ & \pm 4.4 & $73.7^{c}$ & \pm 3.7 & n.s. \\
\hline $\mathrm{C}_{\mathrm{mic}} / \mathrm{N}_{\mathrm{mic}} 1$ & & 5.62 & \pm 0.27 & 5.52 & \pm 0.35 & 4.76 & \pm 0.12 & 4.84 & \pm 0.19 & n.s. \\
\hline $\mathrm{C}_{\mathrm{mic}} / \mathrm{C}_{\mathrm{org}}$ & $\%$ & $2.47 \mathrm{ab}$ & \pm 0.19 & $2.36^{a}$ & \pm 0.19 & $2.77^{a b}$ & \pm 0.22 & $2.7^{\mathrm{b}}$ & \pm 0.2 & 0.02 \\
\hline $\mathrm{MR} / \mathrm{C}_{\mathrm{mic}}$ & $\%$ & $11.1^{\mathrm{a}}$ & \pm 1.27 & $11.7^{\mathrm{ab}}$ & \pm 1.27 & $13.5^{\mathrm{ab}}$ & \pm 1.27 & $14.0^{\mathrm{b}}$ & \pm 1.27 & n.s. \\
\hline $\mathrm{N}_{\text {mic }} / \mathrm{N}_{\text {total }}$ & $\%$ & $3.68^{\mathrm{a}}$ & \pm 0.31 & $3.86^{\mathrm{a}}$ & \pm 0.31 & $5.27^{\mathrm{b}}$ & \pm 0.31 & $5.18^{\mathrm{b}}$ & \pm 0.31 & n.s. \\
\hline Bacterivorous nematodes & individuals $100 \mathrm{~mL}$ soil $^{-1}$ & $546^{\mathrm{a}}$ & \pm 471 & $662^{\mathrm{a}}$ & \pm 469 & $1263^{\mathrm{b}}$ & \pm 478 & $1295^{\mathrm{b}}$ & \pm 474 & 0.03 \\
\hline Fungivorous nematodes & individuals $100 \mathrm{~mL}$ soil $^{-1}$ & 326 & \pm 69 & 313 & \pm 69 & 417 & \pm 69 & 335 & \pm 69 & 0.008 \\
\hline Herbivorous nematodes & individuals $100 \mathrm{~mL}$ soil $^{-1}$ & 568 & \pm 149 & 675 & \pm 149 & 889 & \pm 149 & 924 & \pm 149 & n.s. \\
\hline $\mathrm{Om}+\operatorname{Pr}$ nematodes ${ }^{2}$ & individuals $100 \mathrm{~mL}$ soil ${ }^{-1}$ & 72 & \pm 21 & 118 & \pm 21 & 96 & \pm 36 & 155 & \pm 36 & n.s. \\
\hline
\end{tabular}

${ }^{1} \mathrm{C}_{\text {mic }}, \mathrm{N}_{\text {mic }}$ : Microbial biomass of carbon and nitrogen; MR: Microbial respiration. ${ }^{2}$ Omnivorous (Om) and predatory (Pr) nematodes were pooled due to their overall low abundance. ${ }^{3}$ Mean values for each soil parameter that do not share a common upper-case letter $\left({ }^{\mathrm{a}}, \mathrm{b}, \mathrm{c}, \mathrm{d}\right)$ are significantly different $\left(p<0.05, \mathrm{df}_{\text {tillage }}=7, \mathrm{df}_{\text {fertilizer between tillage }}=7, \mathrm{df}_{\text {fertilizer within tillage }}=14\right)$ according to linear mixed-effects models and estimated marginal means with Tukey corrections for multiple testing. 


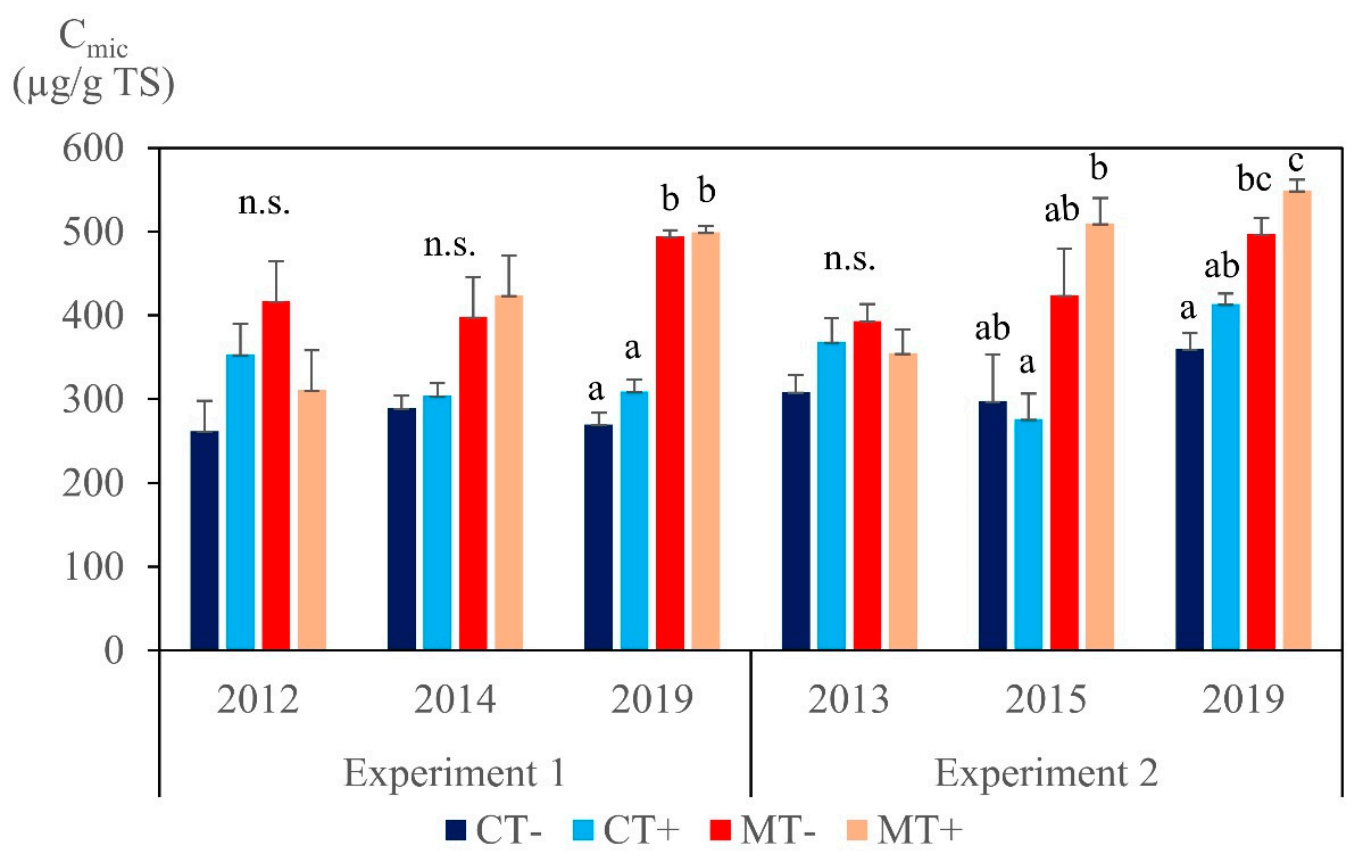

Figure 2. Mean $( \pm \mathrm{SE})$ top soil $(15 \mathrm{~cm})$ microbial biomass carbon $\left(\mathrm{C}_{\mathrm{mic}}\right)$ in $\mu \mathrm{g}$ per $\mathrm{g}$ soil dry matter affected by plow (CT, blue bars) or minimum tillage (MT, red bars), each combined with either yard waste compost application (+, light-colored bars) or mineral potassium and phosphorous application equivalent to contents in the composts (-, dark-colored bars). $C_{\text {mic }}$ was determined two years, four years, and eight/nine years after the start of the experiments (Experiment 1: 2010; Experiment 2: 2011). Mean values of the respective treatments that do not share a common letter for each year and experiment are significantly different $\left(p<0.05, \mathrm{df}_{\text {tillage }}=3, \mathrm{df}_{\text {fertilizer }}=30\right)$ according to linear mixed effects models and estimated marginal means with Tukey correction for multiple testing.

Four years after the start of the experiment, when potatoes had been grown for the first time with mulch application, $C_{m i c}$ was already $39 \%$ and $62 \%$ higher under minimum tillage than under plow tillage in Experiments 1 (2014) and 2 (2015), respectively (Figure 2). At that time, compost application had increased $C_{\text {mic }}$ consistently (6-20\%) in comparison to mineral fertilization in both experiments under minimum tillage.

In $2019, \mathrm{C}_{\text {mic }}$ values were $72 \%$ and $35 \%$ higher under minimum compared to plow tillage in Experiments 1 and 2, respectively. The $\mathrm{C}_{\text {mic }}$ was $15 \%$ higher under plow tillage with compost compared to plow tillage with mineral fertilization (Figure 2). Compost effects under minimum tillage were less pronounced in 2019 than in 2014 and 2015. Similar effects of tillage were observed for the microbial respiration and number of free-living nematodes in both years, which were, on average, $86 \%$ and $64 \%$ higher, respectively, under minimum than under plow tillage (Table 3). In particular, the number of bacterivorous nematodes was three times and two times higher under minimum tillage compared to plow tillage in Experiment 1 and Experiment 2, respectively, which also explains the significance of the interaction of experiment with tillage (Table 3). The absolute number of herbivorous as well as omnivorous/predatory nematodes was $31 \%$ to $46 \%$ higher under minimum tillage compared to plow tillage. Fungivorous nematodes showed no statistical differences among treatments. However, total numbers of fungivorous nematodes showed a different pattern in both years. In the first year (Experiment 1), the total number of fungivorous nematodes was higher under minimum tillage (425 nematodes per $100 \mathrm{~mL}$ soil) compared to plow tillage (173 nematodes per $100 \mathrm{~mL}$ soil), whereas in the second year, it was the opposite, with higher numbers under plow tillage (466 nematodes per $100 \mathrm{~mL}$ soil) compared to minimum tillage (327 nematodes per $100 \mathrm{~mL}$ soil). 


\subsection{Effects of Tillage System and Fertilizer Application on Pea Performance under Greenhouse Conditions}

Overall, pea yield was similar in both experiments. For example, pea aboveground dry weight was 50\% and 39\% higher under minimum tillage compared to plow tillage in Experiments 1 and 2, respectively (Figure A1). Although this effect was less clear for the pea root fresh weight, the highest root weights were generally recorded under minimum tillage (Table 4). Similarly, the number of pods produced per pot was always higher under minimum tillage than under plow tillage.

Table 4. Means $( \pm$ SE) of pea production parameters in both field experiments assessed in a greenhouse experiment. The factors studied were plow and minimum tillage combined with either compost fertilization $\left(<5 \mathrm{t}(\mathrm{ha} \mathrm{a})^{-1}\right)$ or mineral potassium and phosphorous application equivalent to contents in the respective composts.

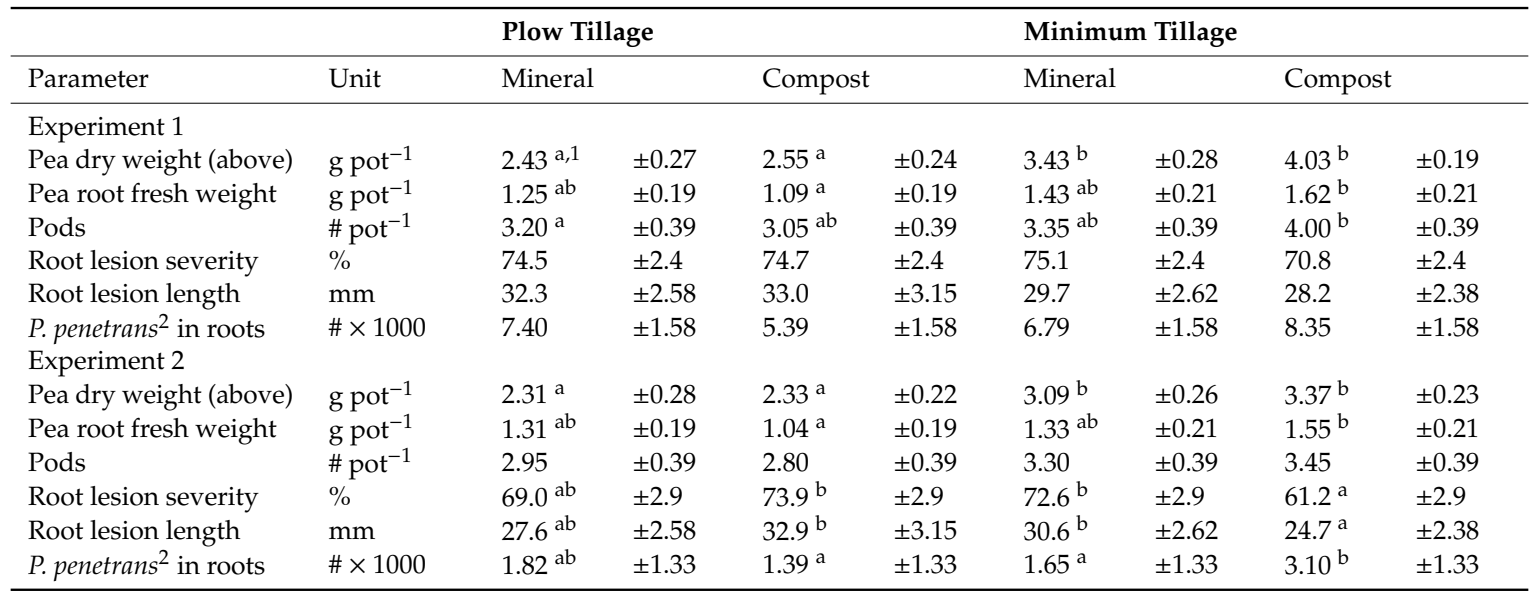

${ }^{1}$ Mean values for each parameter that do not share a common upper-case letter $\left({ }^{\mathrm{a}, \mathrm{b}}\right)$ are significantly different $\left(p<0.05, \mathrm{df}_{\text {tillage }}=38, \mathrm{df}_{\text {fertilizer }}=38, \mathrm{df}_{\text {fertilizer within tillage }}=76\right)$ according to linear mixed-effects models and estimated marginal means with Tukey corrections for multiple testing. ${ }^{2}$ Soils were inoculated with 7000 mixed stages + eggs of P. penetrans pot $^{-1}$.

Root lesion severity and root lesion length were about 5\% higher in Experiment 1 compared to Experiment 2. In general, both disease parameters were similar for the two plow tillage systems and the minimum tillage system that had received mineral fertilizer. However, when peas were grown in soil collected from the minimum tillage system with compost application, root lesion severity and root lesion length were reduced. This effect, however, was only significant in Experiment 2.

The numbers of P. penetrans in roots per pot were 6983 and 1990 in Experiments 1 and 2, respectively. Hence, the final population density divided by the inoculation density was 1 and 0.29 , respectively. In both experiments, the number of P. penetrans was lowest under plow tillage with compost application and highest under minimum tillage with compost.

\subsection{Biological Soil Components as Indicators of Soil Fertility}

In our study, soil fertility was measured by pea biomass production in a greenhouse bioassay after artificial soil inoculation with lesion nematodes (Table 4).

The soil used in the greenhouse and the soil used for the chemical and biological parameter analyses shown in Table 3 were derived from the same composite samples, allowing for a direct link between soil data and ecosystem services, such as biomass production, in the greenhouse experiment (Figure 3). Thus, a number of standard biological "black box" indicators of soil quality, such as $\mathrm{C}_{\mathrm{mic}}$, $\mathrm{N}_{\text {mic }}$, microbial respiration, and $\mathrm{C}_{\text {org }}$, were positively correlated with the pea biomass production in soils of both field experiments (Figure 3). The severity of root lesions further affected pea dry matter in both experiments $\left(r_{s}<-0.51, p<0.46\right.$, Figure 3$)$. 


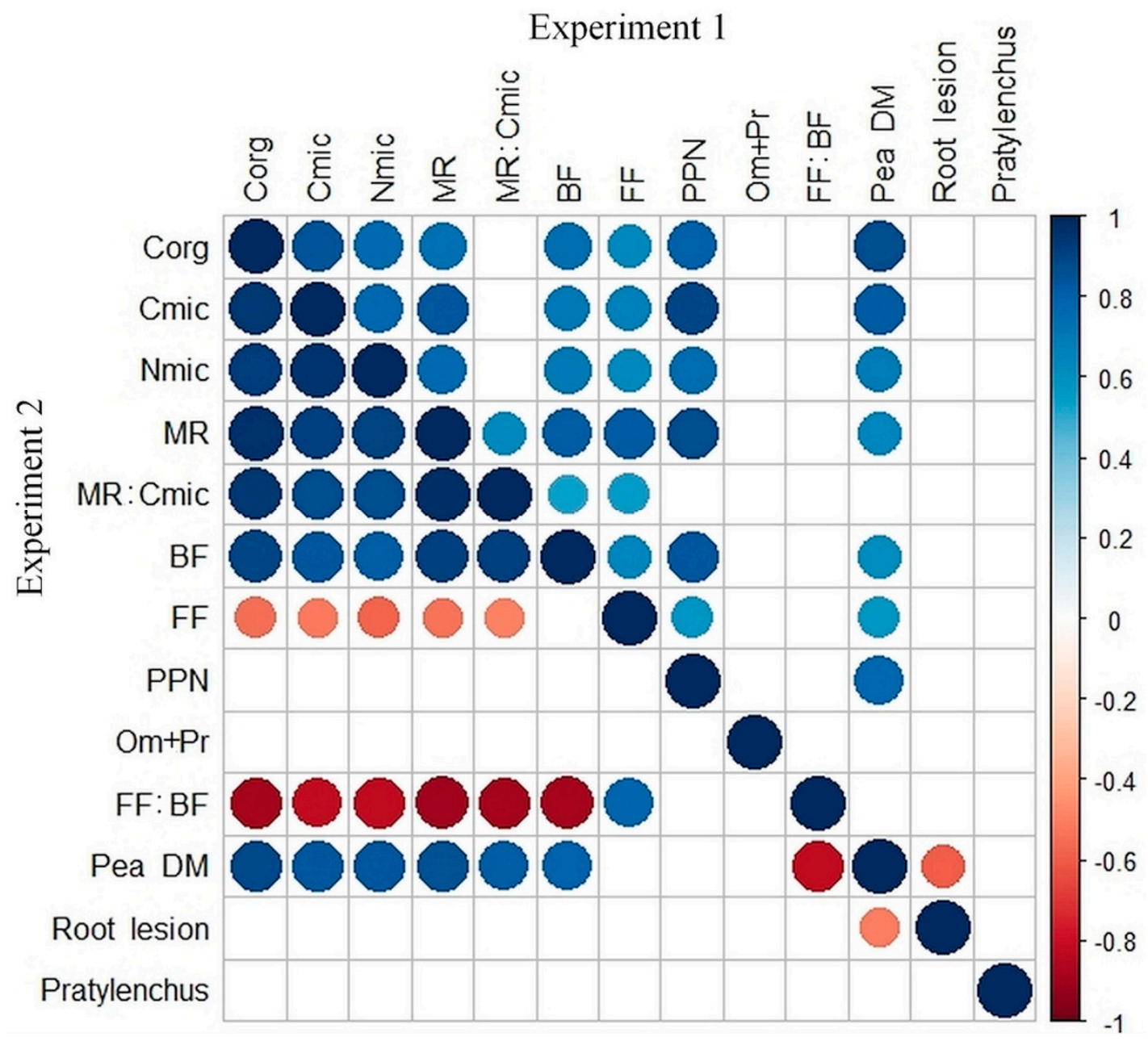

Figure 3. Spearman's $r_{\mathrm{s}}$ correlation coefficients of important biological soil indicators (including $\mathrm{C}_{\text {org }}$ ) independent of applied treatments. Correlations within Experiments 1 and 2 are shown in the upper and lower diagonal, respectively. Positive correlations are displayed in blue and negative correlations in red color. Color intensity and the size of the circle are proportional to the correlation coefficients. In the right side of the correlogram, the legend color shows the correlation coefficients and the corresponding colors. Correlations with $p$-values $>0.05(n=16)$ are considered insignificant and were left blank. Abbreviations: Corg, total organic C; Cmic, microbial biomass C; Nmic, microbial biomass $\mathrm{N}$; $\mathrm{MR}$, microbial respiration; $\mathrm{BF}$, bacterivorous nematodes; $\mathrm{FF}$, fungivorous nematodes; PPN, herbivorous nematodes; $\mathrm{Om}+\mathrm{Pr}$, omnivorous and predator nematodes; Pea DM, pea dry matter; Root lesion, pea root rot; Pratylenchus, Pratylenchus in pea roots. The latter three indicators were assessed in a separate greenhouse experiment.

In addition to these indicators, we also used the abundance of free-living nematodes, which included free-living herbivorous, bacterivorous, fungivorous, and omnivorous/predatory nematodes. In both experiments, the abundance of bacterivorous nematodes was highly correlated with pea dry matter $\left(r_{s}>0.61, p<0.012\right.$, Figure 3$)$, as well as with $C_{m i c}$ and microbial respiration $\left(\mathrm{r}_{\mathrm{s}}>0.7, p<0.003\right.$, Figure 3$)$. The pooled abundance of omnivorous/predatory nematodes, as well as the number of $P$. penetrans in roots per pot, was unaffected by any of the applied parameters. Herbivorous nematodes were positively correlated with pea dry matter in Experiment $1\left(\mathrm{r}_{\mathrm{s}}>0.78, p<0.001\right.$, Figure 3$)$, but not in Experiment $2\left(r_{s}>0.23, p>0.05\right.$, Figure 3). In Experiment 2, fungivorous nematodes correlated negatively with microbial biomass, respiration, and $\mathrm{C}_{\mathrm{org}}$, while the fungivorous-bacterivorous ratio was correlated with reduced pea dry matter yields $\left(\mathrm{r}_{\mathrm{s}}>-0.83, p<0.001\right)$. A minor negative correlation $\left(r_{s}>-0.3, p>0.17\right)$ was observed between the root lesion severity at the stem base and on the roots of 
pea and the number of P. penetrans in roots; however, this effect was not statistically significant in any of the experiments.

\section{Discussion}

In general, nutrient availability is one of the major yield-limiting factors in organic agriculture due to the restrictions on the use of soluble mineral fertilizers. Nutrient deficiencies in organic agriculture may be more prevalent under minimum tillage [7] due to the delay in soil warming and, thus, nutrient mineralization caused by greater aboveground soil cover, which can severely affect early seedling development [2]. The minimum tillage system presented here, combining both cover crops and dead mulch applications, clearly indicates the potential to remedy such nutrient deficiencies. Including cover crops and dead mulch application resulted in greater soil fertility in the top layer compared to the initial levels, including in the plow-based system. Interestingly, potato yields correlated positively with the numbers of free-living nematodes determined in 2019 [6]. In addition to greater soil fertility in the top layer, mulching is an important measure to conserve water, leading to further yield increases, a phenomenon consistently observed with mulched potatoes in the years 2015 and 2016 [38] and also in 2018 and 2019 (Junge, Finckh, et al., unpublished data). The improvement in soil fertility reported here was similar or even greater compared to a long-term organic study from Frick, Switzerland, where phosphorus and potassium were $72 \%$ and $40 \%$ higher in the top $10 \mathrm{~cm}$ of soil following six years of reduced tillage (15-cm-deep two-layer plowing) compared to 30-cm-deep plowing [39]. In the same study, $\mathrm{C}_{\text {org }}$ increased from $2.2 \%$ to $2.6 \%$ under reduced tillage, whereas it remained at $2.1 \%$ with deep plowing. After 15 years of minimum tillage in the same experiment, $\mathrm{C}_{\text {org }}$ contents were increased from $2.2 \%$ to $2.9 \%$ [5], which is similar to the increase in our study after eight and nine years of minimum tillage.

With respect to the similarity of the $\mathrm{pH}$ levels across tillage and fertilizer applications, it could not be determined if there were any differences per se, or if liming of the two field experiments in the month before sampling camouflaged tillage or fertilizer effects on $\mathrm{pH}$. However, in a similar experiment in Austria, where shallow conservation tillage was compared to 25-cm-deep plowing, no significant differences in $\mathrm{pH}$ were found [40]. Likewise, neither tillage, slurry, nor composted manure had any effect on soil pH in the above-described long-term study from Frick, Switzerland [5].

The observed higher salt values under minimum tillage indicate that caution should be taken, as elevated salt concentrations can cause yield depression of salt-intolerant plants, as described for Phaseolus bean and carrots, where threshold levels of about $1 \mathrm{mS} \mathrm{cm}^{-1}$ are given [41]. Comparing the fertilization systems in this study, higher salt contents were generally found for organic fertilization in comparison to mineral fertilization. This is not surprising, as the composts used had high salt contents (EC: $5-10 \mathrm{mS} \mathrm{cm}^{-1}$ ) [21].

The effect of the tillage system on micronutrients has rarely been described. However, it appears that this generally follows the same pattern as that observed for macronutrients, i.e., an enrichment under minimum/zero tillage compared to intensive tillage [42]. Unfortunately, nothing is known about the relevance of these differences in micronutrient concentrations for plant performance. It can only be speculated that the higher micronutrient and macronutrient levels observed in this study may have contributed to the greater biomass production in the pea bioassay under both minimum tillage systems compared to plow tillage (Table 3). For example, boron (and calcium, which has not been assessed here) is known to be important for $\mathrm{N}_{2}$ fixation in legumes and can massively enhance pea aboveground biomass production [43]. However, the contribution of boron to pea growth in this study remains unsolved.

With respect to soil biological properties, our results are confirmed by other studies, which reported that $C_{\text {mic }}$ and microbial activity under minimum tillage are generally higher than under plow tillage $[5,39,44]$. The fact that this was confirmed in two independent field experiments under two different crops-and considering the abundance of bacterivorous nematodes in the present study-indicates the robustness of such measurements. Although soil biological properties can vary 
greatly across the season, Kandeler and Böhm [44] demonstrated that $C_{\text {mic }}$ can already be used as a reliable indicator for changes in soil biology four years after the transition to minimum tillage. This is in line with the findings of our study, where the first clear differentiations between tillage systems occurred two years after differential tillage and four years after minimum tillage (Figure 2, years 2014 and 2015). In addition, we found higher microbial quotients $\left(C_{m i c} / C_{o r g}\right)$ under minimum than under plow tillage. These likely indicate a higher $C$ input, as well as higher $C$ quality for $C_{\text {mic }}$ production [45].

Contrary to our expectations, the microbial quotient $\left(\mathrm{MR} / \mathrm{C}_{\mathrm{mic}}\right)$, which can be used as an indicator of changes in organic matter availability [46], was $21 \%$ higher under minimum tillage compared to plow tillage. This suggests that minimum tillage in combination with dead mulch application induced a lower efficiency in $C$ use compared to the plow system. $C_{\text {org }}$ availability was also found to be one of the main drivers of microbial quotients in a study that compared 30 different textured soils with varying $C_{\text {org }}$ contents [47]. Haynes [46] noted that bacteria are less efficient in utilizing C sources than fungi, which may further explain the higher metabolic quotient under minimum tillage compared to plow tillage in our study. The application of dead mulch with a low to moderate $\mathrm{C} / \mathrm{N}$ ratio $(\sim 25)$ was likely responsible for the breakdown of crop residues, mainly by bacteria. This is supported by a three-fold greater bacterivorous-fungivorous nematode ratio under minimum tillage four months after dead mulch application (Experiment 2) compared to 16 months after dead mulch application (Experiment 1) (data not shown). Specifically, the number of bacterivorous r-strategist Rhabditidae and Panagrolaimidae was enhanced under minimum tillage by $44 \%$ in Experiment 1 and $88 \%$ in Experiment 2 when compared to plow tillage (unpublished data). In contrast to Experiment 1, the recent disturbances in the minimum tillage system in Experiment 2 due to potato production, i.e., tillage for planting, fertilization with nitrogen-rich mulch, and harvesting tillage, likely fostered enrichment opportunists, i.e., bacterivorous nematodes of Rhabditidae and Panagrolaimidae [18,19]. This is confirmed by a study from Canada, where conservation tillage resulted in $17.5 \%$ to $119 \%$ higher numbers of bacterivorous nematodes (Rhabditidae and Diplogasteridae) compared to conventional tillage after potato cropping [48]. The lower $\mathrm{C}_{\text {mic }} / \mathrm{N}_{\text {mic }}$ ratios under minimum compared to plow tillage (Table 3) also suggest a dominance of bacteria over fungi. This is in contrast with the lower bacteria-fungi ratios observed under minimum tillage compared to plow tillage systems under similar climatic conditions [49]. In the aforementioned study of Kuntz et al. [49], the assessment had been performed eight months after the last tillage operation, which could have led to a general succession from bacterial to fungal breakdown of residues. According to Bongers and Bongers [18], the number of Rhabditidae and Panagrolaimidae in soil will decline with decreasing nutrient availability and microbial activity, while the general opportunistic Cephalobidae will become dominant. This occurred in the minimum tillage system in Experiment 1, 16 months after the last mulch application. Further succession under minimum tillage will likely result in fungal breakdown of crop residues and, thus, in an increase of opportunistic fungivorous nematode families (Aphelenchoididae, Aphelenchidae) $[18,20]$. A similar situation likely occurred in the plow tillage system without mulch fertilization in Experiment 1, where the number of fungivorous nematodes was twice as high as that of bacterivorous nematodes (234 nematodes per $100 \mathrm{~mL}$ soil, unpublished). The greater relative abundance of fungivorous as well as omnivorous/predatory nematodes under plow tillage compared to minimum tillage was also observed in a study that compared a no-till with a plow system in a maize-soy bean rotation [50].

The massively enhanced pea biomass production under minimum tillage in the greenhouse assay could be expected based on the generally higher macro- and micronutrient levels compared to the plow-based system. The strong positive effects of compost fertilization under minimum tillage could neither be related to differences in nutrient composition nor to biological properties. Suppression of $P$. penetrans did not play a role in this context, as its numbers were generally highest under minimum tillage with compost. It is likely that the nematodes benefitted from higher root mass and plant nourishment in this treatment. At $C_{\text {org }}$ contents of $<1.4 \%$, the application of $4 \mathrm{t} \mathrm{ha}^{-1}$ of composted pig manure reduced P. penetrans, on average, by $87 \%$ in two pot experiments cropped with sugar beets [51]. Conditions in the plow system of our study were similar; however, the reduction of $P$. penetrans in 
the compost-treated soil was only $25 \%$. In contrast, the root lesion severity was only reduced under minimum tillage with compost. These lesions were likely caused by soil-inhabiting and pea-pathogenic fungi that were commonly found in soils of the study site [14,30]. The negative correlation of root lesion severity and pea biomass production in this study suggests that soil health under minimum tillage with compost fertilization is generally improved. This was also directly translated into a greater soil fertility in terms of pea biomass production. As pointed out above, under field conditions, when there is a lack of rainfall, effects of the mulch and increased soil organic matter contents on water retention may lead to further advantages in practice.

Bacterivorous and fungivorous nematodes contribute substantially to soil fertility as decomposers that release nitrogen to the soil [52,53]. Both feeding types accounted for $50 \%$ and $65 \%$ of the total nematode community in Experiment 1 and 2, respectively, which highlights their importance for greater nutrient turnover and, thus, pea production in our study. Across the globe, organic carbon, which is commonly used as indicator of soil fertility, was found to be one of the main drivers of nematode abundance $[15,54]$. This was also observed for bacterivorous nematodes in both field experiments in our study. However, the fungivorous-bacterivorous nematode ratio was negatively correlated with pea dry matter yields in Experiment 2, which emphasizes that bacterivorous nematodes were more reliable indicators of soil fertility than fungivorous nematodes. This is further supported by the strong positive correlations of bacterivorous nematodes and pea biomass production in both field experiments (Figure 3). In addition, the strong correlations of bacterivorous nematodes with microbial biomass and microbial respiration in both field experiments highlight their usefulness as indicators of a microbially active soil. The fact that predominantly bacterivorous nematodes are categorized into the group of enrichment opportunists [18,55] further strengthens our hypothesis that these are important indicators of soil fertility.

\section{Conclusions}

We conclude that minimum tillage accompanied by regular mulch applications in a system with frequent and diverse use of cover crops in the rotation provides a promising management strategy for sustainable organic crop production. Soil fertility can be improved when converting to minimum tillage, even under organic conditions, if the system is properly adapted, for example, by the use of organic fertilizer. Additional physical, chemical, and biological soil properties besides those investigated in our study may also play a role and should be investigated further in order to fully understand the management-soil-plant interactions reported here. The simple assessment of free-living nematodes and their classification into feeding types provides a useful indicator for soil fertility. Thus, the bacterivorous nematodes were indicators of soil fertility equivalent to other typically used parameters, such as $\mathrm{C}_{\text {org }}, \mathrm{C}_{\mathrm{mic}}$, microbial respiration, and macronutrients. Of course, such analyses could be considerably strengthened by more detailed nematological investigations. The low laboratory costs associated with simple free-living nematode assessments-e.g., nematodes can easily be obtained from Oostenbrink dishes, Baermann funnels, or Cobb's sieves and counted and classified into feeding types under a microscope at 40× magnification [26] - are an additional advantage of using nematodes as bioindicators. Nematode-specific indices, such as maturity, channel, and structure indices, as well as metabolic footprints, will provide more details about the faunal composition that influences the fertility and resilience status of a soil $[19,52,56]$. The nematodes' key positions in the soil food web will thus allow for the tracking of different soil carbon pathways without the use of expensive and specialized equipment, such as those needed for phospholipid fatty acid, chloroform fumigation, ergosterol, and other extractions. However, detailed taxonomic knowledge is required to identify the free-living nematodes at the family and genus levels. In addition, identification at the species level through molecular methods will give a detailed overview of the contribution of single species to a certain ecosystem service, such as plant production, disease suppression, or resilience. In accordance with many other studies, our results clearly demonstrate that nematodes hold great potential for the characterization of management effects. 
Author Contributions: Conceptualization, J.H.S., M.R.F., and J.H.; methodology, M.R.F., J.H., and J.H.S.; investigation, J.H.S.; formal analysis, J.H.S.; writing-original draft, J.H.S.; writing-review and editing, J.H., M.R.F., and J.H.S.; funding acquisition, J.H.S. and M.R.F.; resources, M.R.F. and J.H. All authors have read and agreed to the published version of the manuscript.

Funding: This research was funded by the Deutsche Forschungsgemeinschaft (DFG, German Research Foundation)-Project no. 420414676: "The self-regulatory potential of agro-ecosystems: Using nematodes as indicators for legume disease suppressive soils", by the European Union FP7 Project n.289277: OSCAR (Optimizing Subsidiary Crop Applications in Rotations), and by the German BMBF Project no. FKZ 031A350C: INSUSFAR (Innovative approaches to optimizing genetic diversity for sustainable farming systems of the future).

Acknowledgments: The authors would like to thank Matthias von Ahn and Leonard Theisgen for their excellent assistance in nematode extraction and counting, as well as Elsa Zwicker and Keo Sasha Rigorth for their excellent support in microbial biomass and activity assessments. Furthermore, the authors would like to thank Stephan Junge for provision of potato yield data and field pictures. The authors would like thank Odette D. Weedon for the constructive feedback and proofreading of the manuscript.

Conflicts of Interest: The authors declare no conflict of interest. The funders had no role in the design of the study; in the collection, analyses, or interpretation of data; in the writing of the manuscript, or in the decision to publish the results.

\section{Appendix A}

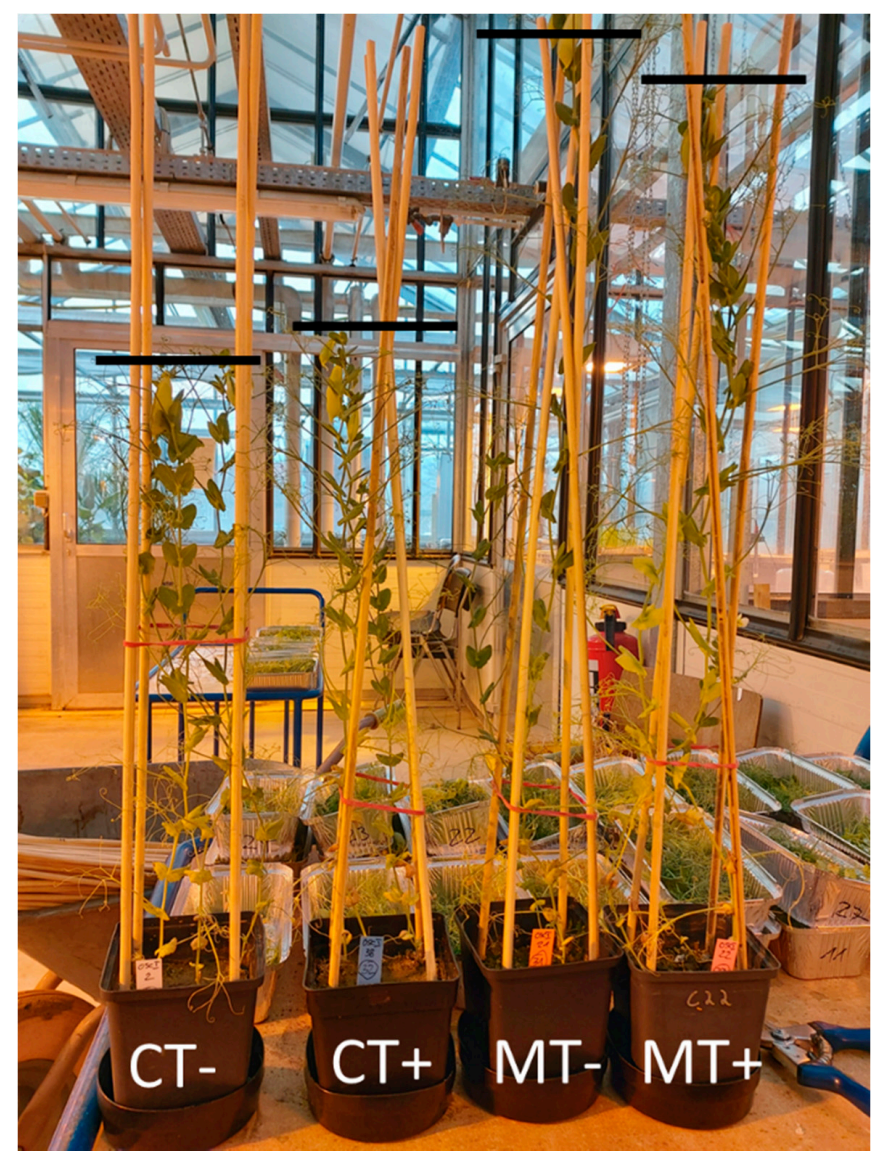

Figure A1. Soil fertility evaluation of four different soils (CT and MT refer to plow and minimum tillage, respectively; + and - refer to compost and equivalent mineral $\mathrm{P}$ and $\mathrm{K}$ fertilization, respectively). Black vertical bars indicate stem lengths of pea plants (Pisum sativum L.) 80 days after planting. For reference, stem lengths from the bottom of the pots are $80 \mathrm{~cm}$, indicating $25 \%$ higher stem lengths under MT compared to CT. 


\section{References}

1. Vincent-Caboud, L.; Casagrande, M.; David, C.; Ryan, M.R.; Silva, E.M.; Peigne, J. Using mulch from cover crops to facilitate organic no-till soybean and maize production. A review. Agron. Sustain. Dev. 2019, $39,45$. [CrossRef]

2. Finckh, M.R.; van Bruggen, A.H.C. Organic production of annual crops. In Plant Diseases and their Management in Organic Agriculture; Finckh, M.R., van Bruggen, A.H.C., Tamm, L., Eds.; American Phytopathological Society: St. Paul, MN, USA, 2015; pp. 25-32. ISBN 978-0-89054-476-1.

3. Cooper, J.; Baranski, M.; Stewart, G.; Lange, M.N.; Bàrberi, P.; Fließbach, A.; Peigné, J.; Berner, A.; Brock, C.; Casagrande, M.; et al. Shallow non-inversion tillage in organic farming maintains crop yields and increases soil C stocks: A meta-analysis. Agron. Sustain. Dev. 2016, 36, 1-20. [CrossRef]

4. Vann, R.A.; Reberg-Horton, S.C.; Poffenbarger, H.J.; Zinati, G.M.; Moyer, J.B.; Mirsky, S.B. Starter fertilizer for managing cover crop-based organic corn. Agron. J. 2017, 109, 2214-2222. [CrossRef]

5. Krauss, M.; Berner, A.; Perrochet, F.; Frei, R.; Niggli, U.; Mäder, P. Enhanced soil quality with reduced tillage and solid manures in organic farming-A synthesis of 15 years. Sci. Rep. 2020, 10, 4403. [CrossRef] [PubMed]

6. Junge, S.M.; Storch, J.; Finckh, M.R.; Schmidt, J.H. Developing organic minimum tillage farming systems for Central and Northern European conditions. In No-till Farming Systems for Sustainable Agriculture: Challenges and Opportunities; Dang, Y.P., Dalal, R.C., Menzies, N.W., Eds.; Springer-Nature: Amsterdam, The Netherlands, 2020; Chapter 11; in press, ISBN 978-3-030-46408-0.

7. Peigné, J.; Vian, J.-F.; Payet, V.; Saby, N.P.A. Soil fertility after 10 years of conservation tillage in organic farming. Soil Tillage Res. 2018, 175, 194-204. [CrossRef]

8. Mirsky, S.B.; Ryan, M.R.; Curran, W.S.; Teasdale, J.R.; Maul, J.; Spargo, J.T.; Moyer, J.; Grantham, A.M.; Weber, D.; Way, T.R.; et al. Conservation tillage issues: Cover crop-based organic rotational no-till grain production in the mid-Atlantic region, USA. Renew. Agric. Food Syst. 2012, 27, 31-40. [CrossRef]

9. Papp, R.; Marinari, S.; Moscatelli, M.C.; van der Heijden, M.G.A.; Wittwer, R.; Campiglia, E.; Radicetti, E.; Mancinelli, R.; Fradgley, N.; Pearce, B.; et al. Short-term changes in soil biochemical properties as affected by subsidiary crop cultivation in four European pedo-climatic zones. Soil Tillage Res. 2018, 180, 126-136. [CrossRef]

10. Schmidt, J.H.; Junge, S.; Finckh, M.R. Cover crops and compost prevent weed seed bank buildup in herbicide-free wheat-potato rotations under conservation tillage. Ecol. Evol. 2019, 9, 2715-2724. [CrossRef]

11. Döring, T.F.; Lynch, D.H. Organic potato cultivation. In Achieving Sustainable Cultivation of Potatoes; Wang-Pruski, G., Ed.; Burleigh Dodds Series in Agricultural Science; Burleigh Dodds Science Publishing: Cambridge, UK, 2018; pp. 89-118. ISBN 978-1-78676-100-2.

12. Finckh, M.R.; Yli-Mattila, T.; Nykänen, A.; Kurki, P.; Hannukkala, A. Organic temperate legume disease management. In Plant Diseases and their Management in Organic Agriculture; Finckh, M.R., van Bruggen, A.H.C., Tamm, L., Eds.; American Phytopathological Society: St. Paul, MN, USA, 2015; pp. 293-310. ISBN 978-0-89054-476-1.

13. Litterick, A.M.; Harrier, L.; Wallace, P.; Watson, C.A.; Wood, M. The role of uncomposted materials, composts, manures, and compost extracts in reducing pest and disease incidence and severity in sustainable temperate agricultural and horticultural crop production-A review. CRC Crit. Rev. Plant Sci. 2004, 23, 453-479. [CrossRef]

14. Baćanović-Šišić, J.; Šišić, A.; Schmidt, J.H.; Finckh, M.R. Identification and characterization of pathogens associated with root rot of winter peas grown under organic management in Germany. Eur. J. Plant Pathol. 2018, 151, 745-755. [CrossRef]

15. Stirling, G.R. Biological control of plant-parasitic nematodes: An ecological perspective, a review of progress and opportunities for further research. In Biological Control of Plant-Parasitic Nematodes; Progress in Biological Control; Davies, K., Spiegel, Y., Eds.; Springer: Amsterdam, The Netherlands; Heidelberg, Germany; London, UK; New York, NY, USA, 2011; pp. 1-38. ISBN 978-1-4020-9648-8.

16. Bünemann, E.K.; Bongiorno, G.; Bai, Z.; Creamer, R.E.; De Deyn, G.; de Goede, R.; Fleskens, L.; Geissen, V.; Kuyper, T.W.; Mäder, P.; et al. Soil quality-A critical review. Soil Biol. Biochem. 2018, 120, 105-125. [CrossRef]

17. Bongers, T. The maturity index: An ecological measure of environmental disturbance based on nematode species composition. Oecologia 1990, 83, 14-19. [CrossRef] [PubMed]

18. Bongers, T.; Bongers, M. Functional diversity of nematodes. Appl. Soil Ecol. 1998, 10, 239-251. [CrossRef] 
19. Bongers, T.; Ferris, H. Nematode community structure as a bioindicator in environmental monitoring. Trends Ecol. Evol. 1999, 14, 224-228. [CrossRef]

20. Neher, D.A. Ecology of plant and free-living nematodes in natural and agricultural soil. Annu. Rev. Phytopathol. 2010, 48, 371-394. [CrossRef]

21. Schmidt, J.H.; Finckh, M.R.; Hallmann, J. Oilseed radish/black oat subsidiary crops can help regulate plant-parasitic nematodes under non-inversion tillage in an organic wheat-potato rotation. Nematology 2017, 19, 1135-1146. [CrossRef]

22. VDLUFA. Methodenbuch Band I Böden, 4th ed.; VDLUFA: Darmstadt, Germany, 1991; Book 1 A 4.1.3.2: Direct assessment of Corg by burning at $550{ }^{\circ} \mathrm{C}$, Book 1 A 5.1.1: $\mathrm{pH}$ in soil-salt $(\mathrm{CaCl})$ solution, Book $1 \mathrm{~A}$ 6.2.1.1: Assessment of phosphorous and potassium in an acidic calcium-acetate-lactate- solution (CAL), Book 1 A 6.2.4.1: Extraction of magnesium with $\mathrm{CaCl}$-solution and subsequent photometric detection, Book 1 A 10.1.1: Calculation of $\mathrm{KCl}$ contents after assessment of electric conductivity, DIN EN ISO 17294-2:2017: Determination of copper, zinc and boron in water via inductively-coupled plasma mass spectrometry, DIN EN ISO 11885:2009: Determination of manganese and iron in water via inductively coupled plasma-optical emission spectrometry, and DIN EN 16168:2012: Assessment of Ntoal via dry burning; ISBN 978-3-941273-13-9.

23. Vance, E.D.; Brookes, P.C.; Jenkinson, D.S. An extraction method for measuring soil microbial biomass C. Soil Biol. Biochem. 1987, 19, 703-707. [CrossRef]

24. Joergensen, R.G. The fumigation-extraction method to estimate soil microbial biomass: Calibration of the kEC value. Soil Biol. Biochem. 1996, 28, 25-31. [CrossRef]

25. Joergensen, R.G.; Mueller, T. The fumigation-extraction method to estimate soil microbial biomass: Calibration of the kEN value. Soil Biol. Biochem. 1996, 28, 33-37. [CrossRef]

26. Hallmann, J.; Subbotin, S.A. Methods for extraction, processing and detection of plant and soil nematodes. In Plant Parasitic Nematodes in Subtropical and Tropical Agriculture, 3rd ed.; Sikora, R.A., Coyne, D., Hallmann, J., Timper, P., Eds.; CABI: Boston, MA, USA, 2018; pp. 87-119. ISBN 978-1-78639-124-7.

27. Bongers, T. De nematoden van Nederland: Een Identificatietabel voor de in Nederland Aangetroffen Zoetwater-en Bodembewonende Nematoden; Natuurhistorische Bibliotheek van de KNNV; 2. druk.; Stichting Uitg. KNNV: Utrecht, The Netherlands, 1994; ISBN 978-90-5011-015-0.

28. Sieriebriennikov, B.; Ferris, H.; de Goede, R.G.M. NINJA: An automated calculation system for nematode-based biological monitoring. Eur. J. Soil Biol. 2014, 61, 90-93. [CrossRef]

29. Castillo, P.; Trapero-Casas, J.L.; Jiménez-Díaz, R.M. Effect of time, temperature, and inoculum density on reproduction of Pratylenchus thornei in carrot disk cultures. J. Nematol. 1995, 27, 120-124. [PubMed]

30. Šišić, A.; Baćanović-Šišić, J.; Karlovsky, P.; Wittwer, R.; Walder, F.; Campiglia, E.; Radicetti, E.; Friberg, H.; Baresel, J.P.; Finckh, M.R. Roots of symptom-free leguminous cover crop and living mulch species harbor diverse Fusarium communities that show highly variable aggressiveness on pea (Pisum sativum). PLoS ONE 2018, 13, e0191969. [CrossRef] [PubMed]

31. Pflughöft, O. Pilzkrankheiten in Körnerfuttererbsen (Pisum sativum L.)—Diagnose, Epidemiologie, Ertragsrelevanz und Bekämpfung. Ph.D. Thesis, Georg-August-Universität, Göttingen, Germany, 2008.

32. R Core Team. R: A Language and Environment for Statistical Computing; R Foundation for Statistical Computing: Vienna, Austria, 2019; Available online: https://www.r-project.org/ (accessed on 19 August 2020).

33. Pinheiro, J.; Bates, D.; DebRoy, S.; Sarkar, D.; authors, E.; Heisterkamp, S.; Willigen, B.V. R-core nlme: Linear and Nonlinear Mixed Effects Models. 2017. Available online: https://rdrr.io/cran/nlme/ (accessed on 19 August 2020).

34. Lenth, R.; Buerkner, P.; Herve, M.; Love, J.; Riebl, H.; Singmann, H. emmeans: Estimated Marginal Means, aka Least-Squares Means. 2019. Available online: https://rdrr.io/cran/emmeans/ (accessed on 19 August 2020).

35. Fox, J.; Weisberg, S. An R Companion to Applied Regression, 2nd ed.; SAGE Publications: Thousand Oaks, CA, USA, 2011; ISBN 978-1-4129-7514-8.

36. Zuur, A.; Leno, E.N.; Walker, N.; Saveliev, A.A.; Smith, G.M. Mixed Effects Models and Extensions in Ecology with R; Statistics for Biology and Health; Springer: New York, NY, USA, 2009; ISBN 978-0-387-87457-9.

37. Harrell, F.E., Jr. Hmisc: Harrell Miscellaneous. 2020. Available online: https://rdrr.io/cran/Hmisc/ (accessed on 19 August 2020). 
38. Finckh, M.R.; Junge, S.; Schmidt, J.H.; Weedon, O.D. Disease and pest management in organic farming: A case for applied agroecology. In Improving Organic Crop Cultivation; Kopke, U., Ed.; Burleigh Dodds Science Publishing: Cambridge, UK, 2018; ISBN 978-1-78676-184-2.

39. Gadermaier, F.; Berner, A.; Fließbach, A.; Friedel, J.K.; Mäder, P. Impact of reduced tillage on soil organic carbon and nutrient budgets under organic farming. Renew. Agric. Food Syst. 2012, 27, 68-80. [CrossRef]

40. Neugschwandtner, R.W.; Liebhard, P.; Kaul, H.-P.; Wagentristl, H. Soil chemical properties as affected by tillage and crop rotation in a long-term field experiment. Plant Soil Environ. 2014, 60, 57-62. [CrossRef]

41. George, E.; Horst, W.J.; Neumann, E. Adaptations of plants to adverse chemical soil conditions. In Marschner's Mineral Nutrition of Higher Plants; Marschner, H., Marschner, P., Eds.; Elsevier/Academic Press: London, UK; Waltham, MA, USA, 2012; pp. 409-472. ISBN 978-0-12-384905-2.

42. Carr, P.; Gramig, G.; Liebig, M.A. Impacts of organic zero tillage systems on crops, weeds, and soil quality. Sustainability 2013, 5, 3172-3201. [CrossRef]

43. Redondo-Nieto, M.; Wilmot, A.R.; El-Hamdaoui, A.; Bonilla, I.; Bolaños, L. Relationship between boron and calcium in the N2-fixing legume-rhizobia symbiosis. Plant Cell Environ. 2003, 26, 1905-1915. [CrossRef]

44. Kandeler, E.; Böhm, K.E. Temporal dynamics of microbial biomass, xylanase activity, N-mineralisation and potential nitrification in different tillage systems. Appl. Soil Ecol. 1996, 4, 181-191. [CrossRef]

45. Sparling, G. Ratio of microbial biomass carbon to soil organic carbon as a sensitive indicator of changes in soil organic matter. Aust. J. Soil Res. 1992, 30. [CrossRef]

46. Haynes, R.J. Size and activity of the soil microbial biomass under grass and arable management. Biol. Fertil. Soils. 1999, 30, 210-216. [CrossRef]

47. Wang, W.J.; Dalal, R.C.; Moody, P.W.; Smith, C.J. Relationships of soil respiration to microbial biomass, substrate availability and clay content. Soil Biol. Biochem. 2003, 35, 273-284. [CrossRef]

48. Carter, M.R.; Noronha, C.; Peters, R.D.; Kimpinski, J. Influence of conservation tillage and crop rotation on the resilience of an intensive long-term potato cropping system: Restoration of soil biological properties after the potato phase. Agric. Ecosyst. Environ. 2009, 133, 32-39. [CrossRef]

49. Kuntz, M.; Berner, A.; Gattinger, A.; Scholberg, J.M.; Mäder, P.; Pfiffner, L. Influence of reduced tillage on earthworm and microbial communities under organic arable farming. Pedobiologia 2013, 56, 251-260. [CrossRef]

50. Neher, D.A.; Nishanthan, T.; Grabau, Z.J.; Chen, S.Y. Crop rotation and tillage affect nematode communities more than biocides in monoculture soybean. Appl. Soil Ecol. 2019, 140, 89-97. [CrossRef]

51. Renčo, M.; Kováčik, P. Response of plant parasitic and free living soil nematodes to composted animal manure soil amendments. J. Nematol. 2012, 44, 329-336. [PubMed]

52. Ferris, H. Contribution of nematodes to the structure and function of the soil food web. J. Nematol. 2010, 42, 63-67.

53. Hallmann, J.; Kiewnick, S. Diseases caused by nematodes in organic agriculture. In Plant Diseases and their Management in Organic Agriculture; Finckh, M.R., van Bruggen, A.H.C., Tamm, L., Eds.; American Phytopathological Society: St. Paul, MN, USA, 2015; pp. 91-105. ISBN 978-0-89054-476-1.

54. Van den Hoogen, J.; Geisen, S.; Routh, D.; Ferris, H.; Traunspurger, W.; Wardle, D.A.; de Goede, R.G.M.; Adams, B.J.; Ahmad, W.; Andriuzzi, W.S.; et al. Soil nematode abundance and functional group composition at a global scale. Nature 2019, 572, 194-198. [CrossRef]

55. Ferris, H.; Bongers, T.; de Goede, R.G.M. A framework for soil food web diagnostics: Extension of the nematode faunal analysis concept. Appl. Soil Ecol. 2001, 18, 13-29. [CrossRef]

56. Ferris, H. Form and function: Metabolic footprints of nematodes in the soil food web. Eur. J. Soil Biol. 2010, 46, 97-104. [CrossRef]

(C) 2020 by the authors. Licensee MDPI, Basel, Switzerland. This article is an open access article distributed under the terms and conditions of the Creative Commons Attribution (CC BY) license (http://creativecommons.org/licenses/by/4.0/). 